DOI 10.4467/2543733XSSB.21.005.13798

JAN RYDEL

Uniwersytet Pedagogiczny w Krakowie

\title{
GENERAL REINHARD GEHLEN I JEGO RAPORT O POLSKIM PODZIEMIU
}

\section{General Reinhard Gehlen and his report on the Polish underground}

\author{
Summary
}

The article presents the brilliant military career of Wehrmacht officer Reinhard Gehlen, who led the intelligence of the German land forces on the eastern front from 1942 to 1945 . He developed this intelligence and became Germany's best expert in the Soviet Army, which made it easier for him to establish close cooperation with the CIA after the war and become head of West German Intelligence (BND). During the war, General Gehlen's intelligence was, among other things, involved in the development of the Polish resistance movement. For this reason, when in the last weeks of the war, the German leadership considered the creation of a major Nazi resistance movement after the Third Reich's capitulation, Gehlen presented an extensive one in April 1945, The final report under the title Militärische und nachrichtendienstliche Kräfte im Gesamtrahmen der Polnischen Widerstandsbewegung [Military and Intelligence Forces within the overall framework of the Polish Resistance], because he considered the Polish underground to be the best resistance movement in Europe. The report contains, among others, positive opinions about the will to survive and the resistance of the Polish society, high professional evaluations of the Polish underground army and even words of admiration for the activities of Polish military intelligence.

Keywords: Second World War, German intelligence, Polish intelligence, Polish resistance, Reinhard Gehlen

Słowa kluczowe: II wojna światowa, wywiad niemiecki, wywiad polski, ruch oporu w Polsce, Reinhard Gehlen

Niemieckie zasoby archiwalne dotyczące historii wojny, okupacji i ruchu oporu w Polsce są, obok sowieckich, jednym z ostatnich jeszcze nie dość wykorzystanych zespołów źródeł do badań nad okresem II wojny światowej. Przekonałem się o tym, sięgnąwszy przed laty do przechowywanego w Bundesarchiv-Militärarchiv we Fryburgu Bryzgowijskim pod 
sygnaturą H3/1509 maszynopisu Militärische und nachrichtendienstliche Kräfte im Gesamtrahmen der Polnischen Widerstandsbewegung [Siły wojskowe i wywiadowcze w ogólnych ramach polskiego ruchu oporu], który nosi datę 4 kwietnia 1945 r. i powstał w kręgu dowodzonej przez generała majora Reinharda Gehlena struktury Sztabu Generalnego Dowództwa Wojsk Lądowych [Oberkommando des Heeres, OKH], noszącej nazwę Fremde Heere Ost [FHO, Obce Wojska Wschód].

Dla właściwego zrozumienia okoliczności powstania tego dokumentu skupimy się najpierw na osobie dowódcy FHO i podległej mu instytucji. Reinhard Gehlen urodził się w 1902 r. w Erfurcie, od 1911 r. żył na Dolnym Śląsku. Po maturze w 1920 r. podjął służbę w Reichswehrze, w 1923 r. awansowany na pierwszy stopień oficerski służył w pułku artylerii w Świdnicy. W 1937 ukończył Akademię Wojenną z drugą lokatą i od wiosny 1939 r. przeniesiony został w stopniu majora na stałe do Sztabu Generalnego Wojsk Lądowych. Miał opinię oficera niezmiernie pracowitego, nieledwie pracoholika, i bardzo zdolnego organizatora, a zarazem człowieka zamkniętego w sobie. Podczas kampanii wrześniowej był szefem sztabu rezerwowej 213. Dywizji Piechoty z Głogowa. Dywizja, która dotarła z Wrocławia przez Łódź do Modlina, nie odegrała w kampanii znaczącej roli. Gehlen, doceniony w tym czasie przez przełożonych, został adiutantem szefa Sztabu Generalnego gen. Franza Haldera, a następnie (od października 1940) kierownikiem Gruppe Ost w Oddziale Operacyjnym Sztabu Wojsk Lądowych. W tym charakterze wyróżnił się podczas przygotowań do operacji „Barbarossa”. Warto zaznaczyć, że Gehlen, będąc zdecydowanym przeciwnikiem komunizmu, już w okresie międzywojennym żywo interesował się ZSRS i jego siłami zbrojnymi ${ }^{1}$.

Wiosną 1942 r. zwolniony został wieloletni dowódca sztabowej komórki Fremde Heere Ost, pułkownik Eberhard Kinzel. Stało się to w następstwie niepowodzenia niemieckiej ofensywy na Moskwę, za co w dużym stopniu obwiniano właśnie FHO i jej dowódcę, ponieważ błędnie ocenił zdolności mobilizacyjne Sowietów i nie rozpoznał przerzutu oddziałów z Syberii pod Moskwę. 1 kwietnia dowódcą FHO został podpułkownik Reinhard Gehlen. W sztabie niemieckich Wojsk Lądowych zadanie oceny stanu i zamierzeń wojsk nieprzyjacielskich (oraz sojuszniczych) podzielone było według kryteriów geograficznych między dwa oddziały, a mianowicie Fremde Heere Ost i Fremde Heere West ${ }^{2}$. Kiedy Niemcy rozpoczynały wojnę, obydwa te oddziały nie były przygotowane do wykonania ogromu zadań, jakie miały na nie spaść. Dość powiedzieć, że w FHO pracowało początkowo zaledwie kilkunastu oficerów. Ponadto, zgodnie z tradycją prusko-niemieckich sztabów, pion rozpoznawczy nie posiadał własnych narzędzi służących do zbierania informacji na temat nieprzyjaciela. Miał otrzymywać stosowne dane od innych służb i podległych związów operacyjnych wojsk lądowych i dopiero na ich podstawie opracowywać oceny nieprzyjaciela i przekazywać je dowódcy lub szefowi sztabu. W warunkach frontu wschodniego podczas II wojny światowej, rozciągającego się od Laponii do podnóży Kaukazu, gdzie walki miały charakter wybitnie dynamiczny i manewrowy, a wysiłek wojenny absorbował całe sowieckie społeczeństwo, tego typu pasywne podejście do sprawy gromadzenia informacji o nieprzyjacielu skazywało FHO na niepowodzenie.

\footnotetext{
${ }^{1}$ M. Pahl, Fremde Heere Ost. Wywiad wojskowy Hitlera, Oświęcim 2015, s. 110-113

${ }^{2}$ Warto zaznaczyć, że Fremde Heere West (FHW) nigdy podczas wojny nie miało znaczenia porównywalnego z FHO.
} 
Gehlen, rozumiejąc potrzeby Wehrmachtu, radykalnie zmienił sposób pracy dowodzonego przez siebie oddziału. Stworzył własne, bardzo efektywne źródło informacji. W znajdującej się pod Giżyckiem [Lötzen] ${ }^{3}$ niewielkiej XIX-wiecznej twierdzy Boyen powstał podlegający FHO specjalny obóz jeniecki, w którym oficerowie Wehrmachtu - znający rosyjski i stosunki panujące w Sowietach - prowadzili przesłuchania jeńców, którzy mogli mieć informacje cenne dla strony niemieckiej i rokowali, że będą współpracować z Niemcami ${ }^{4}$. Zbierano w ten informacje dotyczące głównie morale armii sowieckiej, jej zaopatrzenia, sytuacji na zapleczu frontu i w głębi kraju, stosunku do wyższych dowódców itp. rzadko użytecznych kwestii operacyjnych lub strategicznych ${ }^{5}$. Informacji na ten temat dostarczał silnie rozbudowany niemiecki radiowywiad, działający na kierunku wschodnim ${ }^{6}$. Podlegał on nominalnie wojskom łączności, a w praktyce FHO, gdyż to ludzie Gehlena wkrótce po objęciu przez niego dowództwa wyznaczali mu zadania i przejmowali wyniki nasłuchu. Podobne formy przybrała współpraca z jednostkami Luftwaffe, przeznaczonymi do prowadzenia głębokiego rozpoznania lotniczego. One również podporządkowane zostały FHO pod względem operacyjnym. Z punku widzenia interesującego nas raportu szczególne znaczenie ma podporządkowanie Gehlenowi pewnych części Abwehry, jak potocznie nazywano wywiad podporządkowany Oberkommando der Wehrmacht [OKW, Naczelne Dowództwo Wehrmachtu], noszący od października 1939 r. trudną do przetłumaczenia nazwę Amt Ausland/Abwehr [dosłownie: Urząd Zagranica/Obrona]. Abwehra oprócz klasycznej służby wywiadu zagranicznego, kontrwywiadu oraz własnej łączności posiadała w swych szeregach również strukturę określaną jako Frontaufklärung [FA, Rozpoznanie Frontowe]. Dzieliła się ona na część ukierunkowaną na wschód i na zachód, każda z nich dzieliła się z kolei na trzy oddziały, określone jako Leitstellen [Stanowiska Kierownicze] i oznaczone rzymskimi cyframi I, II i III. Leitstelle I Ost der Frontaufklärung [FA I Ost] zajmowała się płytkim i, jeśli można tak to określić, średnio głębokim wywiadem frontowym. Zadaniem FA II Ost było prowadzenie operacji dywersyjnych za linią frontu. Natomiast FA III Ost prowadziła działalność kontrwywiadowczą na zapleczu niemieckiego frontu wschodniego i w tym charakterze rozpracowywała m.in. polski ruch oporu. Frontaufklärung Ost było zresztą bardzo korzystnie dyslokowane, jak chodzi o zwalczanie tego przeciwnika, gdyż od 1941 r. dowództwa i formacje Rozpoznania Frontowego Wschód aż do 1944 r. stacjonowały w Sulejówku. Dowódca Abwehry, admirał Wilhelm Canaris, rozumiał, że Frontaufklärung Ost pracuje zasadniczo wyłącznie na korzyść OKH, a ponadto cenił Gehlena, toteż już wiosną 1942 r. podporządkował FA I Ost i FA III Ost Obcym Armiom Wschód pod względem operacyjnym. Z czasem doszło do pełnej integracji dwóch wymienionych oddziałów Abwehry z jednostką Gehlena, a oficerowie Frontaufklärung Ost stali się jego najbliższymi współpracownikami?

\footnotetext{
${ }^{3} \mathrm{~W}$ pobliskim Kętrzynie [Rastenburg] znajdowała się polowa kwatera główna Hitlera Wolfsschanze.

${ }^{4}$ Podobno regułą postępowania przesłuchujących było dobre traktowanie jeńców. Co działo się z tymi, którzy odmówili współpracy lub przekazali już wszystko, czym interesowali się oficerowie FHO, nie wiadomo.

${ }^{5}$ M. Pahl, op. cit., s. 130

${ }^{6}$ Por. D. Arazi, Horchdienst und Blitzkrieg: die deutsche Funkaufklärung im Unternehmen „Barbarossa”, [w:] B. Wegner (ed.), Zwei Wege nach Moskau. Vom Hitler-Stalin-Pakt zum ,Unternehmen Barbarossa”, München 1991, s. 221-234.

${ }^{7}$ Ibidem, s. 155-157. Do FHO nie weszła FA II Ost, zajmująca się operacjami typu commando za frontem.
} 
Jednym z najważniejszych źródeł sukcesu pułkownika Gehlena był nowoczesny system dokumentowania zebranych informacji w formie ogromnej kartoteki, w której systematyzowane były wszelkie dane na temat sowieckich jednostek wojskowych, sztabów, dowódców, garnizonów, szkół oficerskich, produkcji zbrojeniowej, nastrojów ludności w różnych rejonach kraju itd. W połączeniu z dużą efektywnością radiowywiadu oraz wkładem lotnictwa i płytkiego wywiadu doprowadziło to do wydatnego i szybkiego zwiększenia stanu wiedzy niemieckiego dowództwa na temat Sowietów. Postęp w tej dziedzinie był bardzo wyraźny m.in. dlatego, że oprócz uczestnictwa samego Gehlena w codziennych naradach w sztabie wojsk lądowych lub w kwaterze głównej Hitlera, FHO zaczęło wydawać na użytek wyższych dowódców Wehrmachtu cotygodniowe i comiesięczne biuletyny, uogólniające wiedzę na temat armii sowieckiej i jej metod prowadzenia wojny. Działania te spowodowały, że FHO zaczęto traktować jak nieledwie wyrocznię, a prestiż Gehlena wzrastał bardzo szybko. O dziwo, nie zrujnowały go nawet tak ciężkie porażki wywiadowcze, jak niedostrzeżenie przygotowań do sowieckiej kontrofensywy pod Stalingradem (listopad 1942) oraz nierozpoznanie zamierzeń sowieckiego dowództwa przed bitwą pod Kurskiem i w jej trakcie (lipiec 1943). W ciągu 1944 r. okazało się jednak, że Hitler stopniowo traci cierpliwość i zaufanie do Reinharda Gehlena. „Führer” coraz bardziej zżymał się na złe wiadomości, jakie przekazywał dowódca FHO, ten jednak potrafił długi czas nie dopuścić do tego, by niełaska dyktatora przerodziła się w jakieś rzeczywiste konsekwencje służbowe.

W tym czasie Reinhard Gehlen, będąc jednym z ludzi mających najpełniejszą wiedzę na temat rzeczywistej sytuacji Niemiec, świadomy był nieuchronności ich klęski. Podjął w związku z tym pierwsze kroki, mające pomóc zarówno jemu, jak i jego zaufanym współpracownikom w urządzeniu się w świecie po Hitlerze. Jak pisze w swych wspomnieniach, wiosną 1944 roku w tajemnicy polecił zaufanym współpracownikom kopiowanie i ukrywanie najcenniejszych materiałów wywiadowczych FHO, aby w chwili zakończenia wojny mieć w ręku jakiś kapitał ${ }^{8}$. Równocześnie żywo zainteresował się polskim ruchem oporu, zarówno ze względu na to, że front przesunął się na tereny nim objęte, jak i z powodu dramatyzmu rozgrywki o przyszłość Polski, toczącej się między Rządem RP na Uchodźstwie w Londynie i lojalnym wobec niego polskim podziemiem wojskowym i cywilnym a Sowietami i ich polskimi poplecznikami, a także między wielkimi mocarstwami. Gehlen wspominał, że obserwacje i przemyślenia na temat Powstania Warszawskiego utwierdziły go w przekonaniu, że sojusz Sowietów z Anglosasami wkrótce po wojnie przerodzi się w ich antagonizm, co spowoduje, że jego wiedza i umiejętności będą znowu w cenie.

20 lipca 1944 r. miała miejsce - jak wiadomo - nieudana próba zamachu na Hitlera i wojskowego przewrotu w III Rzeszy. Gehlen został poinformowany przez spiskowców o przybliżonej dacie zamachu, odmówił im jednak poparcia, uważając, że nie ma on szans powodzenia. Jednocześnie, podobnie jak wielu innych wyższych dowódców Wehrmachtu wiedzących o mającym nastąpić zamachu, zachował tę wiedzę w tajemnicy. Sam jeszcze przed 20 lipca „położył się” do szpitala we Wrocławiu i spędził tam kilka krytycznych tygodni9.

\footnotetext{
${ }^{8}$ R. Gehlen, Der Dienst. Erinnerungen 1942-1971, Mainz 1971, polskie wydanie pt. Sensacyjne wspomnienia szefa wywiadu, Warszawa 1993.

${ }^{9}$ Biografowie uważają, że Gehlen, znający się trochę na medycynie i mający wielu przyjaciół wśród lekarzy, symulował chorobę, aby uniknąć jakichkolwiek podejrzeń.
} 
Rzeczywiście, nie dotknęły go represje, które pochłonęły wiele ofiar, w tym m.in. Canarisa i Haldera, a Fremde Heere Ost miały w Gestapo opinię jedynej komórki Sztabu Generalnego Wojsk Lądowych, w której nie odkryto żadnego spiskowca ${ }^{10}$. Mimo to przyszłość FHO i ich dowódcy była coraz bardziej niepewna, gdyż po zamachu finalizowano podporządkowanie wszystkich służb wywiadowczych Głównemu Urzędowi Bezpieczeństwa Rzeszy [Reichssicherheitshautamt, RSHA], należącemu do imperium Heinricha Himmlera. Prawą ręką Reichsführera SS w sprawach wywiadu zagranicznego był SS-Brigadeführer Walter Schellenberg i on stał się głównym partnerem Gehlena w wyrafinowanej rozgrywce, do jakiej doszło w ostatnich tygodniach wojny.

Spodziewany kres kariery generała majora Reinharda Gehlena w Wehrmachcie nastąpił w pierwszych dniach lutego 1945 r., gdy FHO wydało błędną opinię co do zamierzeń Sowietów po dojściu do Odry. Gehlen przekonywał, że będą oni bez zbędnej zwłoki kontynuowali ofensywę na Berlin, gdy tymczasem Hitler trafnie odgadł, iż zanim przystąią do forsowania Odry, uderzą najpierw na swym prawym skrzydle na umocnienia Wału Pomorskiego [Pommernwall], aby oczyścić północną flankę frontu wschodniego. Ta pomyłka sprawiła, że Gehlen ostatecznie utracił zaufanie Führera, który postanowił o dymisji dowódcy FHO oraz o rozwiązaniu tego bardzo już rozbudowanego oddziału Sztabu Wojsk Lądowych. Od tej pory Gehlen z dnia na dzień czekał na rozkaz odwołujący go z FHO, wykorzystując ten czas na przygotowanie swego rozstania z III Rzeszą. Zadbał przede wszystkim o to, aby zmikrofilmowane już kluczowe materiały FHO, zapakowane w 50 metalowych skrzyń, znalazły się w bezpiecznym miejscu. Początkowo wywiózł je z Zossen pod Berlinem do Naumburga. Wkrótce jednak dowiedział się ze zdobytych dokumentów alianckich, iż to saksońskie miasto znajdzie się w sowieckiej strefie okupacyjnej, toteż rozkazał wyjęcie ich ze skrytek i przewiezienie na południe Niemiec, do rejonu Bad Reichenhall - Berchtesgaden, gdzie planowano urządzenie zapasowej kwatery głównej OKW, a wspomniany teren miał znaleźć się w amerykańskiej strefie okupacyjnej.

Równocześnie Reinhard Gehlen przygotowywał swego rodzaju intrygę, która miała sprawić, że w ostatnich tygodniach wojny będzie mógł de facto zniknąć z powierzchni ziemi. Podją w tym celu rozmowy z Walterem Schellenbergiem. Czy inicjatorem spotkania był Gehlen, czy Schellenberg, pozostaje do tej pory niejasne: wspomnienia Gehlena są w tej kwestii nie całkiem przejrzyste, sugerują wszakże, że inicjatywa była po stronie szefa wywiadu zagranicznego SS, natomiast Schellenberg - przesłuchiwany 12 lipca 1945 r. przez Amerykanów, zeznał, że inicjatorem spotkania i powziętych podczas niego postanowień był Gehlen. Obydwaj wysocy oficerowie, najwyraźniej mający zaufanie do swej dyskrecji, rozważali podczas rozmowy, co powinno wydarzyć się w Niemczech ,ppo Hitlerze”, aby ocalić cokolwiek ze struktur i „,dorobku” III Rzeszy. Rozmówcy doszli do wniosku, że należy stworzyć wielki niemiecki, narodowosocjalistyczny ruch oporu, najlepiej wzorowany na polskim. Jego dowódcą powinien zostać Heinrich Himmler, a Gehlen i Schellenberg mieliby stać się jego zastępcami. Gehlen zaproponował, że przygotuje materiał potrzebny do podjęcia stosownej decyzji, a mianowicie swego rodzaju ekspertyzę

${ }^{10} \mathrm{~W}$ nowszej literaturze niemieckiej szacuje się, że w toku represji bezpośrednio po zamachu aresztowano około 700 osób, spośród których zabito lub skazano na śmierć około 200. W następnych miesiącach aresztowano około 5000 osób uważanych za potencjalnych przeciwników reżimu; por. P. Steinbach, J. Tuchel, Widerstand gegen den Nationalsozialismus: Herausgegeben für die Gedenkstätte Deutscher Widerstand, Weinheim 1994. 
na temat polskiego ruchu oporu. Wiele wskazuje na to, iż to relacja Schellenberga oddaje faktyczny przebieg pamiętnego spotkania ${ }^{11}$. Jak się bowiem wydaje, wszystkie działania Gehlena były ukierunkowane na szybkie i bezpieczne przejście, wraz z najbliższymi współpracownikami i najcenniejszymi zasobami - na stronę amerykańską. W tym celu musiał po zdjęciu go z dowództwa w FHO, co nastąpiło 9 kwietnia 1945 r., zapobiec otrzymaniu przydziału na stanowisko dowódcy dywizji (czy innego związku taktycznego) na froncie, co byłoby zgodne z praktyką Wehrmachtu, ale równałoby się wciągnięciu go w wir zupełnie już beznadziejnych walk. Wykonywanie zlecenia najwyższej wagi dla Reichsführera SS było w tej sytuacji znakomitą wymówką, której zresztą musiał użyć wobec szefa personalnego wojska, zagorzałego nazisty, gen. Wilhelma Burgdorfa.

W takich oto okolicznościach powstał dokument, który nas tu specjalnie interesuje. Jak się wydaje, najpierw współpracownicy Gehlena z Frontaufklärung III Ost przygotowali projekt ekspertyzy, kompilując wcześniejsze dokumenty o podobnym charakterze i dodając aktualne treści. 12 kwietnia 1945 r. Gehlen opuścił kwaterę główną OKH pod Berlinem i wyjechał na południe Niemiec, do rejonu Berchtesgaden. Zajął się tam ostateczną redakcją raportu i zapewne przygotowaniem komentarza do niego. Gotowy dokument zawiózł na północ, do rejonu Flensburga, gdzie przebywał Himmler, zaufany oficer Gehlena, major Horst Hiemenz i przekazał go Walterowi Schellenbergowi, który z kolei w ostatnich dniach kwietnia przedstawił ekspertyzę oraz - niewątpliwie - ideę niemieckiego ruchu oporu samemu Reichsführerowi. Ten, według powojennych zeznań Schellenberga, bez wnikania w szczegóły, w całości ją odrzucił, gdyż stawiałaby go w pozycji głównego defetysty, czego obawiał się, doświadczywszy gniewu Hitlera, który - rozwścieczony podjętymi przez Himmlera próbami porozumienia się z zachodnimi aliantami - pozbawił go wszystkich funkcji partyjnych i wojskowych.

Tymczasem Gehlen - dopilnowawszy ukrycia w górach swych „,bezcennych” materiałów i zorganizowawszy schronienie dla około 40 współpracowników, 28 kwietnia 1945 r. sam udał się wraz z grupą kilku osób do starannie przygotowanej kryjówki w szałasie na izolowanej alpejskiej hali. Po trzech tygodniach zszedł z gór do najbliższego miasteczka i po dwudniowym odpoczynku u przyjaciół oddał się w ręce Amerykanów. Pomimo że od początku informował ich, kim jest i co ma do zaoferowania, przez pierwszych kilka tygodni nie wzbudził ich zainteresowania. Jednak w końcu nastąpił przełom i Gehlen wraz ze swymi materiałami przewieziony został do USA. W lipcu 1946 r., zdobywszy zaufanie nowych mocodawców, dołączył do tworzonej pod skrzydłami amerykańskiego wywiadu w Oberursel przez jego bliskich współpracowników z Wehrmachtu agencji wywiadowczej, mającej początkowo kryptonim Operation Rusty. W lutym 1947 r. objął jej kierownictwo i agencję zaczęto określać jako Organisation Gehlen. W 1956 r. liczyła już kilka tysięcy współpracowników i została przejęta w całości przez Republikę Federalną Niemiec jako Bundesnachrichtendienst (BND). Gehlen kierował nim do $1968 \mathrm{r}$.

Opracowanie Sity wojskowe $i$ wywiadowcze w ogólnych ramach polskiego ruchu opo$r u$ to obszerne przeglądowe opracowanie, liczące 139 stron maszynopisu oraz 41 załącz-

${ }^{11}$ R.-D. Müller, Reinhard Gehlen. Geheimdienstchef im Hintergrund der Bonner Republik. Die Biografie. Teil 1: 1902-1950, Berlin 2017, s. 383-386 oraz powielane wydawnictwo dokumentów CIA History Staff: Kevin C. Ruffner (ed.), Forging an Intelligence Partnership: CIA and the Origins of the BND. 1945-1949, b. m. 1999, dokument 5, s. 17-18. (nsarchive.gwu.edu/NSAEBB/NSAEBB146/doc05.pdf, 12.08.2016). 
ników różnego formatu ${ }^{12}$. Tekst, oprócz Wprowadzenia, składa się z trzech ułożonych chronologicznie części, przy czym zasadniczą cezurą podziału jest Powstanie Warszawskie. Pierwsza z nich Przed Powstaniem Warszawskim omawia sytuację wewnętrzną w Polsce oraz stosunki polsko-niemieckie przed 1939 r., kampanię wrześniową [Der 15-tägige Polenfeldzug], sytuację po jej zakończeniu, oraz w szczególnie obszerny sposób Walkę o naród polski. Rozumie się przez to politykę strony niemieckiej, ,anglo-amerykańskiej”, „sowiecko-rosyjskiej”. Opis polityki polskiej dzieli się na Drogę narodowo-polska oraz Drogę sowiecko-polskq. W każdej z tych „dróg” przedstawia się kwestie polityczne i wojskowe. Osobno omówiono zjawisko konspiracji w Polsce, któremu niemieccy autorzy poświęcili w opracowaniu wiele miejsca, w tym ideę powstania i jego planowanie oraz nielegalną prasę.

Druga część, zatytułowana Powstanie Warszawskie [Der Warschauer Aufstand], omawia decyzję o jego rozpoczęciu, potencjał militarny powstańców, szanse powodzenia, starania o pomoc dla powstania, walkę dyplomatyczną wokół powstania, postawę powstańców i ludności Generalnego Gubernatorstwa oraz kapitulację. Trzecia część opracowania pod tytułem Położenie po Powstaniu Warszawskim przedstawia jego bezpośrednie następstwa, a dalej Ponownq walkę o naród polski i to w dokładnie takim samym układzie, jak w pierwszej części opracowania. Tekst zamyka Podsumowanie, w którym znalazły się podrozdziały Sity charakteru narodowego w polskim ruchu oporu oraz Wojskowe $i$ wywiadowcze sity w polskim ruchu oporu.

Opracowanie jest oczywiście produktem momentu historycznego, w którym powstawało. Były to ostatnie dni przed rozpoczęciem sowieckiej ofensywy znad Odry na Berlin, kiedy w kręgi kierownicze oraz struktury zapewniające funkcjonowanie Rzeszy i Wehrmachtu wdzierać się zaczęły chaos i rozkład, a ścisła elita tego państwa skonfrontowana była ze swym bliskim i nieuchronnym końcem. Wiele wskazuje na to, iż autorzy zajmującego nas opracowania przygotowywali je w pośpiechu, bez dostępu do kompletnych zasobów FHO, ani nawet do przyzwoicie wyposażonej biblioteki publicznej. Świadczy o tym błędnie podany rok śmierci Józefa Piłsudskiego ${ }^{13}$, czyli omyłka nader łatwa do skorygowania w normalnych warunkach. Widać także, że do tekstu opracowania włączone zostały w sposób mechaniczny fragmenty pisane przed początkiem sowieckiej ofensywy styczniowej, czyli przed 12 stycznia 1945 r. Są to rozważania na temat sytuacji Armii Krajowej na Górnym Śląsku i - pisane w czasie przyszłym - dywagacje dotyczące jej możliwego zachowania w wypadku spodziewanej ofensywy sowieckiej. Cała ta partia tekstu była w marcu czy kwietniu 1945 r. de facto pozbawiona sensu i jest z logicznego punktu widzenia zupełnie nie na miejscu. Uważny autor, mający czas zrobić korektę napisanego tekstu, musiałby - naturalnie - ten i podobne błędy zauważyć i zneutralizować, choćby tylko przez odpowiednie zabiegi redakcyjne. Uderza również milczenie na temat rozkazu Komendy Głównej z 19 stycznia 1945 r., rozwiązującego Armię Krajową. Wydaje się, że strona niemiecka powinna być w stanie odnotować tę jedną jeszcze informację. Nie wspomina się także o aresztowaniu przez NKWD przywódców polskiego podziemia 27 marca $1945 \mathrm{r}$. Niewiedza na ten temat nie może jednak dziwić, gdyż fakt aresztowania przez pewien czas

\footnotetext{
${ }^{12}$ Wydanie polskie J. Rydel, A. Sowa (opracowanie naukowe), Polskie podziemie w oczach wroga. Tajny raport dowódcy niemieckiego wywiadu gen. Reinharda Gehlena, Kraków 2016.

${ }^{13}$ J. Rydel, A. Sowa (wyd.), Polskie podziemie..., s. 36
} 
nie był jasny nawet dla polskiego podziemia. Niemniej jednak ignorancja w kwestii tego aresztowania wskazuje, gdzie leżała granica możliwości niemieckiego wywiadu. Inne, nader ważne partie tekstu, jak np. rozważania na temat sytuacji Polski po rychłym zakończeniu wojny, są bez wątpienia pisane w marcu lub kwietniu 1945 r. Zastanawia milczenie autorów raportu w sprawie aresztowania Stefana Roweckiego „Grota” oraz fakt, że nie ujawnia się jego tożsamości, a nawet pseudonim podawany jest w zniekształconej formie „Grod”. Te braki w tekście nasuwają pytanie, czy możliwe jest, aby FHO oraz FA III Ost nie wiedziały o tym fakcie. Jak wiemy, „Grota” aresztował i więził pion RSHA i SS, czy jest jednak możliwe, że nie poinformowano Wehrmachtu. Raczej nie! Prawdopodobnie fakt ujęcia „Grota”, a zapewne też jego uśmiercenia po wybuchu powstania w Warszawie, był w tych kręgach dobrze znany. Jednak pisanie o tym w dokumencie, który w dniach klęski mógł wpaść w niepowołane ręce, postrzegano zapewne jako niedopuszczalne ryzyko. Uważny czytelnik raportu ma w ogóle wrażenie, że jego tekst formułowano w ten sposób, aby - w przypadku gdyby rzeczywiście wpadł on w ręce wroga - nie stanowił podstaw do oskarżenia jego autorów i zleceniodawców. Co przy tym ważne, wrogiem byli zarówno zwycięscy alianci, jak i bezwarunkowi zwolennicy Hitlera, gotowi zabijać zdrajców i defetystów do ostatniego dnia wojny.

W opracowaniu Sity wojskowe i wywiadowcze w ogólnych ramach polskiego ruchu oporu nie znajdziemy ścisłych danych na temat ,,rozpracowanych” przez Niemców polskich siatek wywiadowczych i konspiracyjnych struktur, ani tym bardziej sensacyjnych informacji o niemieckiej agenturze w Armii Krajowej. Z tego zapewne powodu polscy historycy do tej pory nie zwrócili baczniejszej uwagi na omawiany dokument ${ }^{14}$. Obecnie dysponujemy jego skomentowanym polskim przekładem, który ukazał się w formie książkowej pod tytułem Polskie podziemie w oczach wroga. Tajny raport dowódcy niemieckiego ruchu oporu gen. Reinharda Gehlena (Wydawnictwo M, Kraków 2016). Pomimo nieco przesadnie sensacyjnej oprawy graficznej, tom zawiera kompletny i ścisły przekład zasadniczego tekstu raportu oraz tłumaczenia lub faksymile większości załączników. Tekst poprzedza wstępny komentarz profesora Andrzeja Leona Sowy i piszącego te słowa, wyjaśniający, czym jest raport i proponujący pewną interpretację tego specyficznego dokumentu. Przypisy do zasadniczej części tekstu weryfikują zawarte w raporcie informacje o polskim podziemiu, konfrontując niejako ustalenia niemieckich autorów z obecnym stanem wiedzy na ten temat.

Osoby badające polskie podziemie jako takie skorzystają zapewne najbardziej z licznych w aneksach danych na temat polskiej komunikacji radiowej w czasie II wojny światowej oraz z rozsianych w tekście pośrednich dowodów, potwierdzających ustalenia gen. Mariana Zacharskiego, odnoszące się do faktu złamania przez niemiecki wywiad wielu polskich szyfrów używanych w komunikacji radiowej. Mam na myśli na przykład uderzająco szczegółowe informacje na temat finansowania AK i Delegatury Rządu przez Londyn w ostatniej fazie wojny ${ }^{15}$. Ciekawe dla całościowego obrazu polskiego podziemia są bardzo

\footnotetext{
${ }^{14}$ Dokument FHO wykorzystany był do niedawna jedynie w pracy: M. M. Drozdowski (wyd.), Mocarstwa wobec powstania: wybór dokumentów i materiatów, Warszawa 1994.

15 J. Rydel, A. Sowa (wyd.), Polskie podziemie..., s. 162. Pisał o tym obszernie M. Zacharski, Kody wojny. Niemiecki wywiad elektroniczny w latach 1907-1945 a losy polskich, sowieckich, alianckich kodów i szyfrów, Prusim 2015. Por. także artykuł tego samego autora Ocena niemieckiego wywiadu elektronicznego w latach 1918-1945, „Prace Komisji Historii Wojen i Wojskowości PAU”, t. X (2016), s. 117-121.
} 
wysokie oceny niemieckich ekspertów, odnoszące się do oddziałów AK, które w okresie „Burzy” zostały zmobilizowane i ujawniły się wobec Niemców, podejmując walkę zbrojną na dużą skalę, a co najważniejsze, po zakończeniu „Burzy” - najwyraźniej bezproblemowo zniknęły z powierzchni ziemi, powracając do pełnej konspiracji, co wzbudziło podziw niemieckich ekspertów.

To, co w omawianym opracowaniu - zdaniem piszącego te słowa - było do tej pory nieznane polskiej historiografii, to niemieckie charakterystyki postaw polskiego społeczeństwa wobec klęski i okupacji, opinie na temat fenomenu polskiej konspiracji i działań powstańczych oraz działalności polskiego wywiadu. Co charakterystyczne, język niemieckiego raportu opisującego te kwestie jest zastanawiającą mieszaniną suchego stylu sztabowców, zwrotów charakterystycznych dla niemczyzny okresu nazizmu oraz języka antropologii nieledwie. Oto kilka charakterystycznych fragmentów raportu:

$\mathrm{Na}$ ogólnoeuropejskiej mapie oporu to właśnie polski ruch oporu jest w wielu dziedzinach wiodący i wzorcowy. Sytuacja etnogeograficzna narodu polskiego, której charakterystyczne rysy nieomylnie rozpoznajemy w polskim ruchu oporu, jest naznaczona trwaniem od stuleci w strefie ścierania się interesów niemieckich i rosyjskich, toteż musiał się on zawsze bronić przed atakami z obu stron. [...] Stosunek Polaka do Niemców oparty jest na przekonaniu, że musi bronić przed nimi swego terenu osadniczego i życiowego w obszarze Wisły oraz siebie samego jako narodu. Uważa przy tym Niemców za większe egzystencjalne zagrożenie niż Rosjan. [...] To, iż niemiecko-polski konflikt ma charakter historyczny, podkreśla jeszcze jego ostrość i rzekome nieprzejednanie ${ }^{16}$.

Pisząc o podejmowanych przez stronę niemiecką podczas wojny próbach porozumienia z Polakami, autorzy raportu formułują charakterystyczny wywód:

Znamienne jest, że warstwa przywódcza narodu polskiego w wysokim stopniu nordycka i w dużej części mająca w żyłach niemiecką krew uparcie odrzucała porozumienie. [...] Z odwrotną sytuacją mieliśmy do czynienia wśród niższych warstw narodu, mających przeważnie słowiańskie korzenie, które wielokrotnie okazywały gotowość do porozumienia z Niemcami. Ale również te środowiska w coraz większym stopniu przestawały traktować niemieckie propozycje, a zwłaszcza działania (przede wszystkim wyznaczenie nowych granic czy polityka narodowościowa) jako akceptowalną podstawę do takiego porozumienia. Wręcz przeciwnie, narastało przekonanie, że Niemcy chcą brutalnie zniszczyć naród polski, a wszystkie propozycje porozumienia, z jakimi wychodziła strona niemiecka, były albo nieszczere, bądź też były wynikiem niemieckich porażek ponoszonych na frontach. W istocie nie znalazła się żadna polska osobistość, która pozyskałaby naród polski dla niemieckiej przebudowy Europy ${ }^{17}$.

Zaskakujące są również rozważania autorów raportu na temat źródeł siły polskiego ruchu oporu:

Poprzez zlewanie się różnych form działalności wywiadowczej, partyjnej i administracyjnej na rzecz jednego zbrojnego ruchu, siła polskiego oporu osiagga swą prawdziwą głębię i staje się naprawdę niebezpieczna. W takim ruchu oporu sektor cywilny i wojskowy łączą się, generując totalne zaangażowanie członków, przy czym odwaga i gotowość do ponoszenia najwyż-

\footnotetext{
${ }^{16}$ J. Rydel, A. Sowa (wyd.), Polskie podziemie..., s. 31.

${ }^{17}$ Ibidem, s. 40-41.
} 
szych ofiar nie są tylko pustym frazesem, lecz codziennie stosowanym życiowym prawem. Musimy sobie zatem zdawać sprawę, że nie mamy tu do czynienia z jakąś niegroźną grą pozorów, lecz ze śmiertelnie poważnym przekonaniem dwudziestomilionowego - bądź co bądź - narodu, który uznał, że zbrojny opór wobec Niemiec jest jego ultima ratio. Lata, jakie upłynęły od 1939 r., pokazały aż nadto wyraźnie, jakie sukcesy można osiagnnąć, stosując taki opór. Mimo zastosowania najostrzejszych środków przez policję i wojsko, stronie niemieckiej nie udało się ani ograniczyć, ani powstrzymać lawinowego narastania zbrojnego ruchu oporu [...]. Dowodzi to raz jeszcze, że siły polskiego oporu są tak zakorzenione w bycie narodu, iż ich eliminacja środkami wojskowymi i policyjnymi jest wykluczona. Polska klęska w 1939 r. była tylko z pozoru totalna, ponieważ najważniejszy element w życiu narodów, wola posiadania własnego narodowego państwa, nie uległa załamaniu ${ }^{18}$.

Jeszcze o oporze i statusie podludzi:

W tej woli oporu i zwycięstwa niektóre czynniki ujawniają się szczególnie mocno. Jest to przede wszystkim tęsknota za pełniążycia oraz różnorodnymi możliwościami jej doznania. Tam, gdzie Polakom ogranicza się te możliwości, tam gwałtownie wybucha ich sprzeciw. Można odnieść wrażenie, że chodzi tu w mniejszym stopniu o ograniczenie jako takie, lecz o wiele bardziej o zniszczenie pełni życia. Świadomość, że sprowadzono ich do człowieczeństwa „drugiej kategorii” z ograniczonym - w porównaniu z Niemcami - prawem do korzystania z pełni życia, dręczyła Polaków bardziej niż utrata państwowej niepodległości ${ }^{19}$.

\section{Uwagi o konspiracji jako zjawisku społecznym:}

Konspiracja umożliwia prowadzenie własnego życia poza oficjalną rzeczywistością, którą określa „okupant”, i obejmuje wszystkie gałęzie życia państwowego i narodowego, od nielegalnego aparatu państwowego aż do niepozornej, nielegalnej pomocy społecznej. [...] W ten sposób jest ona nie tylko organizacyjno-taktycznym środkiem do zakamuflowania zaplanowanych, konkretnych działań czy bronią małej grupy spiskowców. Oczywiście chodzi o to także, ale przede wszystkim konspiracja jest sprawą całego narodu. Nie znamy takiego zjawiska w naszym narodzie. Zdolność do konspiracji jest głęboko zakorzeniona w charakterze narodowym Polaków i wyuczona w procesie rozwoju historycznego. Dlatego w 1939 r. nie trzeba było jej się uczyć, ani tym bardziej nakazywać. Była ona po prostu oczywistością. [...] Każdy Polak sam z siebie staje się wspierającym, nośnym elementem otaczającej go całości. Dla organizacji ruchu oporu, wyrosłych na takiej glebie, konspiracja jest nie tylko jedną z wielu stosowanych broni, lecz jest tą bojową formą życia, w której przywódcy i naród [...] połączeni są tą samą wolą oporu, tworząc wspólnotę o godnej uwagi sile ${ }^{20}$.

\section{I o powstaniu:}

Gdy mówimy o powstaniu, zwłaszcza z punktu widzenia zwycięzcy z 1939 roku, to mamy na myśli opór przeciwko istniejącemu porządkowi i obowiązującemu prawu. Powstańcy to rebelianci, albo - zgodnie z dzisiejszym zwyczajem językowym - bandyci [Banditen - JR]. Jesteśmy skłonni przyjmować, że całe narody gotowe są podporządkować się nam bez szemrania, a tylko pewne elementy zakłócają spokój. Taki punkt widzenia prowadzi do zwodniczego wniosku, że eliminacja buntowniczych przywódców zdusi w zarodku niepokoje, a duch oporu znik-

\footnotetext{
${ }^{18}$ Ibidem, s. 65-66.

${ }^{19}$ Ibidem, s. 165.

${ }^{20}$ Ibidem, s. 84-85.
} 
nie. Taka interpretacja tego pojęcia jest zbyt wąska, aby pokazać, czym dla Polaków jest powstanie jako norma życia w oporze. [...] Powstanie uznawane jest za akt najwyższej moralności, próbę wymagającą największej odwagi, bezwarunkowego zaangażowania na rzecz własnego narodu [...] jest źródłem siły w czasie najcięższych prób, jest nigdy niegasnącą nadzieją w sytuacjach bez wyjścia. [...] Z tego powodu powstania (tak długo jak żyje naród) nie można zlikwidować za pomocą środków policyjno-wojskowych. Na miejsce tych, którzy odeszli, ciągle pojawiają się nowi ${ }^{21}$.

\section{O polskim wywiadzie:}

Przed 1939 r. polski wywiad był skupiony pod względem organizacyjnym w Oddziale II polskiego Sztabu Generalnego ${ }^{22}$. [...] Jak bardzo rozbudowany był ten wywiad i jak wielkie znaczenie miał zarówno w Polsce jak i w całej Europie, i to od wielu lat, wynika jednoznacznie z akt II Oddz., które zdobyliśmy podczas kampanii polskiej. Liczna, znakomicie wyszkolona i nadzwyczaj uzdolniona siatka agentów oplotła (i nadal oplata) całą Europę. [...] Ciężkie ciosy zadane w latach 1942-43 polskiemu wywiadowi przez niemieckie służby policyjne i wojskowe, dzięki wglądowi w jego szeroko rozgałęzioną agenturę oraz wyniki jego pracy, pozwoliły z całą ostrością dostrzec stopień zagrożeń, jakie on stwarzał. Dotychczasowe niemieckie działania kontrwywiadowcze świadczą o tym, że przy użyciu samych tylko środków wojskowych oraz policyjnych nie można wyeliminować polskiego wywiadu. Co prawda udało się zadać mu wiele ciosów, ale nie udało się go rozbić. Bez względu na to, gdzie i jak go ugodziliśmy, w krótkim czasie wracał do poprzedniej formy, ucząc się z porażek. Jego metody są coraz bardziej wyrafinowane, jego natura jest coraz bardziej zakonspirowana, a przez to coraz trudniejsza do ogarnięcia $^{23}$.

Polski wywiad wniósł znaczący wkład w rozwój ogólnoeuropejskiego ruchu oporu przeciw niemieckiej budowie Nowej Europy. Wspomnieć należy, że polski wywiad, najprawdopodobniej słusznie, podejrzewany jest o udział w zdradzie krajów sprzymierzonych ${ }^{24}$.

Polak kocha odmianę, zmienność wydarzeń, gdyż przynoszą one bogactwo przeżyć. Brzydzi się stałością. [...] Zmiany kursu, nagłe przekształcenia taktyki oraz zmienność uzgodnień dotyczących zasad konspiracji, szyfrów i kwestii technicznych są na porządku dziennym. Są one świadomie stosowane i tworzą preferowany środek w rękach przywódców. Można uznać je za przyczynę znakomitej pracy polskiego wywiadu, ponieważ doskonale nadają się do kamuflażu oraz wprowadzania przeciwnika w błąd. W ten sposób zrozumiała staje się przewaga, jaką polski wywiad zapewnił sobie nad innymi wywiadami mocarstw europejskich ${ }^{25}$.

Polski wywiad utrzymywany był przez Anglię, co bez wątpienia powodowało pewną zależność i ograniczenie swobody. Mimo to wywiad zachował swój narodowy charakter i utrzymał dominującą pozycję w polskim ruchu oporu. Jest on całą swą istotą nastawiony ofensywnie i znamionują go znaczne umiejętności dostosowawcze. Polski wywiad jest wśród naszych wrogów przeciwnikiem szczególnie twardym i niebezpiecznym ${ }^{26}$.

Pochwała polskiego wywiadu, docenienie potencjału polskiego podziemia, podziw dla woli przetrwania i oporu polskiego narodu - to są tony, jakich piszący te słowa nigdy

\footnotetext{
${ }^{21}$ Ibidem, s. 85-86.

${ }^{22}$ Tak w oryginale. Od 1928 r. instytucja ta nazywała się Sztabem Głównym.

${ }^{23}$ J. Rydel, A. Sowa (wyd.), Polskie podziemie..., s. 51-53.

${ }^{24}$ Ibidem, s. 55. Autorzy raportu mają na myśli prawdopodobnie zerwanie sojuszu z Niemcami przez Węgry, Słowację i Rumunię.

${ }^{25}$ Ibidem, s. 167-168.

${ }^{26}$ Ibidem, s. 173.
} 
wcześniej nie odnotował, badając niemieckie źródła i literaturę z okresu drugiej wojny światowej. Ich istnienie dowodzi, jak bardzo potrzebne, a właściwie konieczne dla weryfikacji lub falsyfikacji wielu naszych ustaleń i przekonań, odnoszących się do historii Polski podczas drugiej wojny światowej, jest możliwie najpełniejsze wykorzystanie źródeł wytworzonych przez nieprzyjaciela. Jest to szczególnie ważne w dobie, gdy za granicą i w kraju podejmuje się próby odwrócenia biegunów dotychczasowych narracji o Polsce i Polakach tamtego okresu.

\section{Bibliografia}

Arazi D., Horchdienst und Blitzkrieg: die deutsche Funkaufklärung im Unternehmen „Barbarossa”, [w:] Bernd Wegner (ed.), Zwei Wege nach Moskau. Vom Hitler-Stalin-Pakt zum ,Unternehmen Barbarossa", München 1991.

Drozdowski M. M. (wyd.), Mocarstwa wobec powstania: wybór dokumentów i materiałów, Warszawa 1994.

Gehlen R., Der Dienst. Erinnerungen 1942-1971, Mainz 1971; polskie wydanie: Sensacyjne wspomnienia szefa wywiadu, Warszawa 1993.

Müller R.-D., Reinhard Gehlen. Geheimdienstchef im Hintergrund der Bonner Republik. Die Biografie. Teil 1: 1902-1950, Berlin 2017.

Pahl M., Fremde Heere Ost. Hitlers militärische Feindaufklärung, Berlin 2012; polskie tłumaczenie: Fremde Heere Ost. Wywiad wojskowy Hitlera, Oświęcim 2015.

Pahl M., Die Abteilung Fremde Heere Ost unter Führung von Reihard Gehlen: ein ,Hort des Widerstandes" oder eine verbrecherische Organisation”, [w:] Manuel Becker, Christoph Studt (wyd.), Die Ämter und ihre Vergangenheit im „Dritten Reich”. „Horte des Widerstandes” oder ,, verbrecherische Organisationen", Augsburg 2013.

Rydel J., Sowa A. (wyd.), Polskie podziemie w oczach wroga. Tajny raport dowódcy niemieckiego wywiadu gen. Reinharda Gehlena, Kraków 2016.

Steinbach P., Tuchel J., Widerstand gegen den Nationalsozialismus: Herausgegeben für die Gedenkstätte Deutscher Widerstand, Weinheim 1994.

Jens W., Die Organisation Gehlen und die USA. Deutsch-amerikanische Geheimdienstbeziehungen, Berlin 2008.

Zacharski M., Kody wojny. Niemiecki wywiad elektroniczny w latach 1907-1945 a losy polskich, sowieckich, alianckich kodów i szyfrów, Prusim 2015.

Zacharski M., Ocena niemieckiego wywiadu elektronicznego w latach 1918-1945, „Prace Komisji Historii Wojen i Wojskowości PAU”, t. X (2016), s. 117-121.

Jan Rydel, prof. dr hab., historyk, kierownik Katedry Stosunków Międzynarodowych i Studiów Obszarowych w Instytucie Nauk o Polityce i Administracji Uniwersytetu Pedagogicznego w Krakowie. Bada stosunki polsko-niemieckie i polsko-austriackie w XIX, XX i XXI wieku, międzynarodową politykę pamięci i historię wojska. Jest reprezentantem Polski w Europejskiej Sieci Pamięć i Solidarność oraz w zarządzie Polsko-Niemieckiej Fundacji na rzecz Nauki. 